\title{
Aplikasi Media Pembelajaran Pada Kelas 4 Tema 8 Subtema 3 Bangga Terhadap Daerah Tempat Tinggalku di VIN 2 Kebonagung Imogiri Bantul
}

\author{
Rizki Maulinisa \\ Aprinaldo Anrada \\ Program Magister Universitas Islam Negeri Sunan Kalijaga Yogyakarta. \\ rmaulinisa@gmail.com,aldoanrada@gmail.com
}

Abstract: The learning media used in the process of learning Theme 8 Subtema 3 Proud of the Region where I live in grade 4 at MIN 2 Kebon Agung Imogiri Bantul is internet and projector media. This media is very commonly used by teachers. In its learning activities the media is used to convey material about various production and professional activities that exist around students through pictures and videos. The obstacle in the learning media application is that teachers have difficulty in determining the media used because not all material can use interesting media. This is also due to the teacher's limitations in mastering learning media. But in the learning process, many students have understood the material by using learning media. Apart from all that, there are still students who do not understand the material because the teacher does not pay attention to all student activities in class. Many students play during learning. Classroom learning begins with showing pictures and videos related to the material to be explained, then the teacher will provide stimulus questions to students. The problem is that 
teachers have difficulty choosing a fixed learning media, this is also related to the teacher's limitations in mastering learning media.

Keywords: Learning, Media.

Abstrak: Media pembelajaran yang digunakan dalam proses pembelajaran Tema 8 Subtema 3 Kebanggaan Daerah Tempat Tinggal Saya Kelas 4 MIN 2 Kebon Agung Imogiri Bantul adalah media internet dan proyektor. Media ini sangat umum digunakan oleh para guru. Dalam kegiatan pembelajarannya media digunakan untuk menyampaikan materi tentang berbagai kegiatan produksi dan profesional yang ada disekitar siswa melalui gambar dan video. Kendala dalam penerapan media pembelajaran adalah guru kesulitan dalam menentukan media yang digunakan karena tidak semua materi dapat menggunakan media yang menarik. Hal ini juga disebabkan oleh keterbatasan guru dalam menguasai media pembelajaran. Namun dalam proses pembelajaran, banyak siswa yang telah memahami materi dengan menggunakan media pembelajaran. Terlepas dari semua itu, masih terdapat siswa yang kurang memahami materi karena guru kurang memperhatikan seluruh aktivitas siswa di kelas. Banyak siswa bermain selama belajar. Pembelajaran di kelas dimulai dengan memperlihatkan gambar dan video terkait materi yang akan dijelaskan, kemudian guru akan memberikan pertanyaan stimulus kepada siswa. Permasalahannya adalah guru kesulitan memilih media pembelajaran yang tetap, hal ini juga terkait dengan keterbatasan guru dalam menguasai media pembelajaran.

Kata Kunci : Pembelajaran, Media.

\section{Pendahuluan}

Gerlach dan Ely dalam Hamdani mengatakan bahwa media apabila dipahami secara garis besar adalah manusia, materi, atau kejadian yang membangun kondisi yang membuat siswa mampu memperoleh pengetahuan, keterampilan, atau sikap. ${ }^{1}$ Media yang menarik akan

\footnotetext{
1 Hamdani, Strategi Belajar Mengajar, (Bandung: CV Pustaka Setia), 72.
} 
mempengaruhi hasil belajar siswa. Ketika siswa mengikuti proses pembelajaran siswa dapat memahami apa yang diberikan oleh guru itu menarik maka ia akan terdorong atau merasa tertantang untuk mengetahui apa yang akan disampaikan oleh guru sehingga proses belajar akan menjadi lebih menyenangkan. Terlebih lagi media harus dikembangkan setiap pembelajaran yang akan dilaksanakan dikelas, dengan pengembangan media maka suasana pembelajaran akan menjadi tersusun dalam proses bahan ajar yang dilakukan.

Seperti diketahui pengembangan merupakan suatu proses yang dipakai untuk mengembangkan dan memvalidasi prosuk pendidikan baik berupa proses, produk, dan rangcangan. ${ }^{2}$ Media adalah segala sesuatu yang dapat digunakan untuk menyalurkan pesan dari pengirim ke penerima sehingga dapat meransang pikiran, perasaan, minat serta perhatian siswa sedemikian rupasehingga proses belajar terjadi. ${ }^{3}$ Jadi pengembangan media adlaah suatu prose yang dipakai dalam mengembangkan sebuah produk dengan memberikan stimulus kepada siswa dalam proses pembelajaran.

Dalam pembelajaran dibutuhkan hubungan komunikasi yang baik antara guru dengan siswa untuk meningkatkan hasil pembelajaran yang optimal dari proses pembelajaran bisa berjalan dengan efektif. Untuk menunjang hasil yang baik dibutuhkan sebuah media untuk membantu guru dalam menyamaikan materi yang diajarkan agar dalam proses pembelajaran tidak terkesan membosankan dan tidak menarik. Akan tetapi penggunaan media harus sesuai dengan karatkeristik siswa dengan menyesuaikan bahan apa yang sekiranya dapat mencuri perhatian siswa.

\section{Kerangka Teori}

\section{Pengertian Media Pembelajaran}

Menurut Djamarah, kata media berasal dari bahasa latin dan merupakan bentuk jamak dari kata "medium" yang secara harfiah

2 Punaji Setyosari, Metode Penlitian Pendididkan dan Pengembangan, (Jakarta: Prenamedia Group, 2013), 277.

3 Arif S Sadiman, Media Pendidikan Pengertian, Pengembangan dan Pemanfaatannya, (Jakarta: PT RajaGrafindo Persada, 2011), 7. 
berarti perantara atau pengantar". Dengan demikian, Media adalah segala alat yang digunakan oleh guru dalam proses belajar. Jadi, media dapat memudahkan seorang guru dalam mengajar, selain itu penggunaan media dapat membangkitkan hasil belajar siswa. ${ }^{4}$ Sudiman dalam haling mengemukakan bahwa kata media berasal dari bahasa latin yang secara harfiah berarti "perantara" atau "pengantar". 5

Sebagai suatu sistem, proses pembelajaran terdiri atas beberapa komponen yang satu sama lain saling berinteraksi. Komponen-komponen itu antara lain tujuan, materi pelajaran, metode atau strategi pembelajaran, media dan evaluasi. Media pembelajaran memiliki kedudukan yang pokok dalam proses pembelajaran. dengan kata lain, tanpa adanya media pembelajaran, maka sangat dimungkinkan proses pembelajaran tidak akan terselenggara dengan optimal, efektif, dan efisien. Atau dalam istlah bahwa "media merupakan bagian integral dari sistem pembelajaran, sehingga akan terkait dengan komponen lainya. ${ }^{6}$

Media pembelajaran merupakan sesuatu yang bersifat menyalurkan pesan dan dapat meransang pikiran, perasaan dan kemauan audio siswa sehingga dapat mendorong terjadinya proses belajar pada dirinya. ${ }^{7}$ Oleh karena itu media pembelajaran dapat diartikan sebagai sesuatu yang mengantarkan pesan pembelajaran antara pemberi pesan yakni guru kepada penerima pesan yakni siswa. ${ }^{8}$

Media pembelajaran adalah segala sesuatu seperti alat, lingkungan, dan segala bentuk kegiatan yang dikondisikan untuk menambah pengalaman, mengubah sikap dari batasan ini minimal ada dua hal yang harus dipahami. Pertama, media pembelajaran tidak terbatas pada alat saja

${ }_{4}$ Djamarah Syaiful Bahri, Strategi Belajar Mengajar, Cet-4 (Jakarta: Reineka Cipta), hlm. 120

5 Haling Abdul, Perencanaan Pembelajaran, Cet-4 (Makasar: Badan Penerbit UNM), hlm. 93

6 Wina Sanjaya, Media Komunikasi Pembelajaran, (Jakarta: Kencana Pramedia Group, 2012), 19.

7 Asnawir dan Basyiruddin Usman, Media Pembelajaran, (Jakarta: Ciputat Pers. 2002), 11.

${ }^{8}$ Sri Anitah, Media Pembelajaran, (Surakarta: Yuma Pustaka, 2010), 4. 
seperti $\mathrm{TV}$, radio, dan $\mathrm{CD}$, akan tetapi meliputi pemanfaatan lingkungan baik didesain maupun untuk pembelajaran serta kegiatan yang sengaja dirancang untuk mencapai tujuan pembelajaran. Kedua, media digunakan untuk menambah pengetahuan, mengubah sikap atau digunakan untuk menanamkan keterampilan tertentu, ini berarti dalam alat dan kegiatan yang dirancang itu mengandung pesan tertentu. Ini berarti dalam alat dan kegiatan yang dirancang itu mengandung pesan tertentu sesuai dengan tujuan penggunaan media itu sendiri. Media pembelajaran sendiri dapat dipahami sebagai "segala sesuatu yang dapat menyampaikan atau menyalurkan pesan dari suatu sumber secara tertentu. Sehingga terjadi lingkungan belajar yang kondusif dimana peerimanya dapat melakukan proses belajar secara efisien dan efektif. ${ }^{9}$

Batasan lain telah pula dikemukakan oleh AECT (Association of Education and Comuniation Tecnology, 1997), memberi batasan tentang media sebagai segala bentuk dan saluran yang digunakan untuk menyampaikan pesan atau informasi. Di samping sebagai sistem penyampai ataun pengantar, media yang sering diganti dengan kata mediator, menurut fleming dalam (Azhar Arsyad) adalah penyebab atau alat campur tangan dalam dua pihak dan mendamaikanya. Dengan istilah mediator, media menunjukkan fungsi atau perannya, yaitu alur hubungan yang efektif antara dua pihak utama dalam proses belajar siswa dan isi pembelajaran yang melakukan peran mediasi, mulai dari guru sampai kepada peralatan paling canggih, dapat disebut media. Ringkasnya, mrdia adalah alat yang menyampaikan atau mengantarkan pesan pembelajaran. ${ }^{10}$

\section{Landasan teori}

Pemerolehan pengetahuan dan keterampilan, perubahan-perubahan sikap dan perilaku dapat terjadi karena interaksi antara pengalaman baru dengan pengalaman yang pernah dialami sebelumnya. Menurut Bruner ada tiga tingkatan utama modus belajar, yaitu pengalaman langsung

9 Rayandra Asyhar, Kreartif Mengembangkan Media Pembelajaran, (Jakarta: Gaung Persada Press, 2011), 8.

${ }^{10}$ Azhar Arsyad, Media Pembelajaran, XVI (Jakarta: RajaGrafindo Persada Pers, 2013), 3-4. 
(enactiv), pengalaman piktoral/gambar (iconic), dan pengalaman abstrak atau (symbolic). Urian diatas memberikan petunjuk bahwa agar proses belajar mengajar dapat berhasil, peserta didik diajak untuk memanfaatkan semua alat inderanya. Guru berupaya untuk menampilkan ransangan (stimulus) yang dapat diproses dengan berbagai indera. Dengan demikian, peserta didik diharapkan akan dapat menerima dan menyerap dengan mudah dan baik pesan-pesan dalam materi disajikan

Levie dan Levie yang membaca kembali hasil-hasil penelitian tentang belajar melalui stimulus gambar dan stimulus kata atau visual dan verbal menyimpulkan bahwa stimulus visual membuahkan hasil belajar yang lebih baik untuk tugas-tugas seperti mengingat, mengenali, mengingat kembali, dan menghubung-hubungkan fakta dan konsep. Dipihak lain, stimulus verbal memberikan hasil belajar yang lebih apabila pembelajaran ingatan yang berurut-urutan (cekuensial). ${ }^{11}$

Dalam media pembelajaran terdapat landasan dalam penggunaan media pembelajaran itu sendiri yang mana akan menjadi dasar dari penggunaan media pembelaharab antara lain landasan filosofis, landasan psikologis dan landasan teknologis dirangkup sebagai berikut.

a. Landasan Fislosifis

Menggunakan berbagai jenis media hasil teknologi didalam kelas akan berakibat pada proses pembelajaran. Dengan kata lain penerapan teknologi dalam media pembelajaran akan menjadi dehumanisasi. Akan tetapi, siswa dihargai dan diberikan kebeban untuk menentukan pilihan baik dalam pemilihan alat belajar.

b. Landasan Psikologis

Dengan memperlihatkan kompleks dan uniknya proses belajar, maka ketepatan pemilihan media dan metode pembelajaran akan sangat berfengaruh terhadap hasil belajar siswa. Di samping itu, persepsi siswa juga sangat mempengaruhi hasil belajar. Oleh karena itu, dalam pemilihan media, di samping memperlihatkan komleksitas dan keunikan proses belajar, memahami makna perspesi serta faktor-faktor

${ }^{11}$ Sukiman, Pengembangan Media Pembelajaran, (cet.1, Yogya: Pedagogia, 2012), 30-31. 
yang berfengaruh terhadap penjelasana hendaknya dioptimalkan agar proses pembelajaran dapat berlangsung secara efektif.

c. Landasan Teknologis

Sejalan dengan perkembangan ilmu pengetahuan dan teknologi, teknologi komunikasi dan informasi mengalami kemajuan yang sangat pesat untuk selanjutnya berfengaruh terhadap pola komunikasi dimasyarakat. Tuntutan masyarakat yang semakin besar terhadap pendidikan serta kemajuan ilmu pengetahuan dan teknologi membuat pendidikan tidak mungkin lagi dikelola dengan cara tradisional. Hasil teknologi sendiri telah lama dimiliki oleh sistem pendidikan. ${ }^{12}$

\section{Pengembangan Media Pembelajaran}

Pengembangan media pembelajaran perlu mempertimbangkan beberapa langkah dalam proses pembuatannya, yakni:

a. Penyusunan rancangan

Dalam pembuatan media perlu persiapan dan perencanaan yang teliti dnegan menganalisisis kebutuhan dan karakteristik siswa yang meliputi kemampuan, keterampilan, dan sikap siswa yang mereka miliki sekarang

b. Penulisan

Dalam pokok-pokok materi instruksional yang telah ada, untuk penyajiannya dapat disampaikan melalui media yang dituangkan dalam tulisan dan gambar yang disebut dengan masalah pengembangan program media.

c. Produksi media

Setelah penulisan dilakukan, maka selanjutnya yakni memproduksikan media yang telah dirancang dan siap disajikan kepada siswa.

\footnotetext{
${ }^{12}$ Azhar Arysad, Media Pembelajaran, (Jakarta: RajaGrafindo Persada, 2011), 14.
} 
d. Evaluasi media

Evaluasi ini dilakukan untuk mengetahui apakah media yang dibuat tersebut dapat mencapai tujuan-tujuan yang telah ditetapkan atau tidak. ${ }^{13}$

Dengan adanya berbagai macam media pembelajaran yang semuanya dapat dipakai dalam kegiatan pembelajaran maka sebelum digunakan guru harus memilih media yang mana paling tepat untuk mencapai tujuan pembelajaran yang telah dirumuskan. Karena dalam memilih dan mengembangakan media pembelajaran yang tepat akan membuat proses belajar semakin efektif dan hasil yang di inginkan pasti akan tercapai. Maka dari itu dalam pengembangan media pembelajaran dapat diaktualisasikan dengan cara pengembangan media pembelajaran berbasis media visual, media berbasis audio visual dan media berbasis komputer.

1). Media Berbasis Visual

Media visual adalah media yang hanya dapat dilihat dengan menggunakan indra penglihatan. Jenis media itulah yang sering digunakan oleh para guru untuk membantu menyampaikan isi materi pelajaran. Media visual terdiri atas media yang diantaranya yakni, visualisasi pesan, informasi atau konsep yang ingin disampaikan kepada siswa dapat dikembangkan dalam berbagai bentuk, seperti foto, gambar/ilustrasi, sketsa/gambar garis. ${ }^{14}$

2). Media Berbasis Audio Visual

Media audio adalah media yang mengandung pesan dalam bentuk auditif (hanya dapat didenganr) yang dapat merangsang pikiran, perasaan, perhatian dan kemampuan para siswa untuk mempelajari bahan ajar. Media audio visual merupakan bentuk media pembelajaran yang murah dan terjangkau. Sekali kita membeli tape dan peralatan, seperti recorder, maka hampir tidak diperlukan lagi biaya tambahan, karena tape dapat dihapus setelah digunakan dan pesan baru direkam kembali. Disamping menarik dan memotivasi

\footnotetext{
${ }^{13}$ Arif S Sadiman, Media Pendidikan Pengertian, Pengembangan dan Pemanfaatan..., hlm. 99

${ }^{14}$ Hamdani, Strategi Belajar Mengajar..., hlm. 248
} 
siswa untuk mempelajari materi lebih banyak, materi audio dapat digunakan untuk:

a). Mengembangkan keterampilan mendengar dan mengevaluasi apa yang telah didengar;

b). Menjadikan model yang akan ditiru oleh siswa;

c). Menyiapkan variasi yang menarik dan perubahan tingkat kecepatan belajar mengenai suatu pokok bahasan atau suatu masalah.

3). Media Berbasis Komputer

Selain digunakan untuk keperluan administrasi dan pengembangan usaha pada perusahaan besar dan kecil, komputer pun mendapatkan tempat disekolah-sekolah. Dinegara maju, komputer sudah digunakan disekolah-sekolah dasar sejak tahun 1980-an dan kini disetiap sekolah, komputer sudah menjadi barang yang lumrah. Seperti yang telah dikemukakan sebelumnya, penggunaan komputer sebagai media pembelajaran dikenal dengan nama pembelajaran dengan bantuan komputer (Computer Assisted Instrution - CAI atau Computer Assisted Learning - CAI). Dilihat dari situasi belajar, di mana komputer digunakan untuk tujuan menyajikan isi pelajaran CAI bisa berbentuk tutorial, drill and practice, simulasi, dan permainan. ${ }^{15}$

\section{Metode Penelitian}

\section{Jenis Penelitian}

Adapun jenis penelitian ini adalah penelitian yang menggunakan pendekatan kualitatif, yaitu penelitian yang menghasilkan data deskriptif. Penelitian ini dapat dikategorikan sebagai penelitian lapangan, yaitu penelitian yang dilakukan secara intensif, terperinci dan mendalam terhadap suatu organisasi, lembaga, atau gejala tertentu yang dalam hal peneiti terjun langsung ke lokasi penelitian di MIN 2 Kebonagung.

\footnotetext{
${ }^{15}$ Cecep Kustandi, Media Pembelajaran, (Cet.1, Bogor: Penerbit Ghalia Indonesia, 2013), 98-106
} 


\section{Collecting Data}

\begin{tabular}{|l|l|l|}
\hline \multicolumn{1}{|c|}{ Data } & Sumber Data & Tehnik pengumpulan data \\
\hline $\begin{array}{l}\text { Penggunaan Media } \\
\text { - Tujuan Pembelajaran }\end{array}$ & Guru & Observasi dan Wawancara \\
\hline Materi yang di ajarkan & Guru & $\begin{array}{l}\text { - Wawancara } \\
\text { Dokumentasi (buku } \\
\text { pelajaran) }\end{array}$ \\
\hline - Respon siswa & Siswa & - Wawancara \\
\hline
\end{tabular}

\section{Instrumen Penelitian}

a. Pedoman observasi di kelas IV pada saat pembelajaran subtema

b. Pedoman wawancara untuk menggali informasi penggunaan media pembelajaran

c. Pedoman wawancara untuk menggali infomasi tentang materi yang di ajarkan

d. Pedoman wawancara untuk menggali infomasi tentang tujuan pembelajaran

e. Pedoman wawacara untuk respon siswa dan pemahaman siswa

f. Alat dokumentasi

\section{Tempat Penelitan}

Penelitian ini bertempat di MIN 2 Imogiri Bantul Yogyakarta dengan pertimbangan lokasi yang mudah dijangkau dan memudahkan peneliti serta tidak mengalami kesulitan dalam melakukan penelitian. Yang menjadi objek penelitian adalah siswa-siswi kelas 4 dengan jumlah siswa sebanyak 33 orang dan satu guru Wali Kelas.

\section{Teknik Pengumpulan Data}

Untuk memperoleh data-data yang lengkap dan relevan, maka peneliti menggunakan teknik pengumpulan data sebagai berikut:

a. Observasi 

b. Wawancara
c. Dokumentasi

\section{Hasil Penelitian Dan Pembahasan}

\section{Hasil Penelitian}

a. Deskripsi materi pelajaran yang diajarkan

Dalam kegiatan pembelajaran dikelas, siswa telah sampai pada tema 8 di semester 2 yakni pada subtema 3 dengan materi Bangga Terhadap Daerah Tempat Tinggalku. Dalam materi pelajaran tersebut terdapat 3 muatan mata pelajaran yang hendak di ajarkan yakni muatan PPKn, Bahasa Indonesia, dan IPS. Namun dalam implementasi proses pembelajaran dikelas, guru hanya terpaku pada satu pelajaran yakni IPS. Muatan Pelajaran PPKn dan Bahasa Indonesia sama sekali tidak ditampakan bahkan tidak dibahas sama sekali semala kegiata pembelajaran. Hal ini bisa terjadi karena guru dibatasi waktu dan terkendala proses pembelajaran yang bersamaan dengan kegiatan UAS siswa kelas 6 SD.

b. Deskripsi media pembelajaran yang digunakan

Media pembelajaran adalah alat yang digunakan oleh guru guna menyampaikan materi pelajaran. Media pembelajaran juga digunakan untuk mempermudah siswa dalam memahami materi yang diajarkan dikelas. Pada kegiataan pembelajaran kelas 4 B pada tema 8 subtema 3 guru menggunakan media pembelajaran internet dan proyektor. Media internet digunakan untuk mencari informasi yang terkait dengan pelajaran pada subtema 3 yakni bangga terhadap daerah tempat tinggal ku kemudian, media proyoktor digunakan untuk menyampaikan pelajaran baik yang berasal dari buku siswa maupun sumber informasi lainnya. Media proyektor digunakan untuk menampilkan slide gambar dan vidio dalam hal ini yang berhubungan dengan materi berbagai macam profesi disekitarku namun yang menjadi kendala dalam penggunaan media ini adalah sarana WIFI disekolah tersebut belum tersedia ditambah lagi jika siswa diminta mengakses informasi tentang materi pembelajaran maka akan rawan 
siswa membuka situs-situs atau konten yang kurang baik. Media proyektor yang digunakan oleh guru belum tersedia dan jumlahnya juga tidak banyak disekolah tersebut.

Media pembelajaran yang digunakan dikelas juga terkendala beberapa masalah yakni suara dari video yang ditampikan itu tidak ada sehingga siswa mengalami kesulitan dalam memahami isi materi pada pembelajaran ini guru mengalamikesulitan dalam pemilihan pembelajaran karena tidak semua materi pembelajaran dapat disampaikan melalui media yang bersifat kongkrit kemudian guru juga mengalami kesulitan dalam menguasai media pembelajaran yang disusun atau dibuat

c. Analisis pencapaian tujuan pembelajaran

Pada kegiatan pembelajaran dikelas tersebut yang menjadi tujuan pembelajaran seperti yang tercantum di dalam RPP adalah :

1). Dengan kegiatan berdiskusi mengenai keberagaman karakteristik individu siswa dapat mengetahui sikap untuk menghadapi perbedaan karakteristik antar teman dan manfaat yang diperoleh.

2). Dengan kegiatan melakukan pengamatan jenis pekerjaan masyarakat dilingkungan tempat tinggal siswa, siswa dapat mengelompokkan jenis-kenis pekerjaan yang menghasilkan barang dan jenis-jenis pekerjaan yang menghasilkan jasa.

Berdasakan dua tujuan diatas jika dilihat dari media pembelajaran yang digunakan ketecapaian media pembelajaran hanya berhasil di dapat pada point kedua sebab guru hanya berfokus pada satu muatan mata pelajaran oleh karena itu tujuan pembelajaran pada point pertama dianggap belum tercapai. Ketidak tercapaian nya satu dari dua tujuan pembelajaran disebabkan oleh proses pembelajaran yang diberikan guru hanya berfokus pada beberapa siswa tertentu sementara siswa-siswa yang lain tidak terlalu diperhatikan pada hal pemahaman sikap dan pengetahuan tentang perbedaan karakteristik teman-teman siswa dikelas.

d. Analisis media pembelajaran

1). Penguasaan guru dalam penerapan media pembelajaran 
Guru yang mengajarkan pembelajaran tersebut adalah wali kelas di kelas 4 dalam hal media pembelajaran guru telah beberpa kali menggunakan media pembelaaran dikelas. Dalam hal penguasaan media pembelajaran guru tersebut dianggap telah mampu menguasai media pembelajaran karena hal ini bukan pertama kalinya bagi guru tersebut dalam menggunakan media pembelajran dipembelajaran sebelumnya guru bahkan mendatangkan bebrapa orang dengan profesi yang berbeda sebagai salah satu upaya untuk menggunakan media yangnemarik bagi siswa. Namun tidak semua guru mampu menguasai media pembelajaran beberapa diantaranya mengalami kesulitan dalam penguasaan media pembelajaran atas hal tersebut, diharapkan guru lebih bisa meningkatkan dan melatih penguasaan media pembelajaran.

Namun, guru terkendala pada fasilitas sekolah seperti jumlah proyektor dan fasilitas internet. Sekolah tersebut memiliki dua bangunan sekolah. Gedung barat dan timur. Fasilitas internet hanya ada pada gedung barat. Sedangkan gedung timur belum tersedia layanan internet. Hal ini diharapkan menjadi salah satu pertimbangan sekolah dalam pemenuhan fasilitas yang dapat menunjang proses pembelajaran.

2). Kesesuaiaan antara penggunaan media pembelajaran dengan materi yang diajarkan

Kesesuaian media pembelajaran dengan materi adalah hal yang penting sebab dalam penyampaian materi, jika media yang digunakan tidak sesuai maka siswa akan mengalami kesulitan, dan kebingungan dengan media yang digunakan. Oleh sebab itu, sebelum menentukan media pembelajaran, guru sebaiknya menganalisis terlebih dahulu materi yang akan diajarkan juga media yang tepat digunakan. Barulah setelah itu media pembelajaran dapat disiapkan.

Media yang digunakan adalah media proyektor dan internet. Media yag digunakan sesuai dengan materi yang di ajarkan namun dalam penyampaian hanya berpusat pada satu 
muatan mata pelajaran saja yaitu IPS. Muatan PPKn dan Bahasa indonesia sama sekali tidak dibahas dan di tampilkan dalam media pembelajaran. Kesesuaian dilihat dari beberapa video dan gambar yang ditampilkan telah sesuai dengan pembelajaran walaupun tidak mencakup keseluruhan muatan materi pelajaran.

3). Kelebihan dan kekurangan media yang digunakan

Dari hasil penelitian yang dilakukan, terdapat beberapa kelebihan dan kekurangan dalam media yang digunakan, seperti dibawah ini:

Kelebihan:

» Melalui media ini siswa dapat mengidentifikasi kegiatan apa saja yang ada pada gambar.

» Melalui media tersebut, wawasan siswa dapat berkembang dan lebih luas.

Kelemahan:

Terkait keterampilan berfikir abstrak. Di kelas tersebut terdapat beberapa siswa yang tidak bisa mengidentifikasi kegiatan ekonomi yang ada pada gambar yang ditampilkan guru. Siswa sekolah dasar pada usia 7-12 tahun berada pada perkembangan cara berfikir konkret. Jadi jika materi yang disampaikan bersifat abstrak maka perlu adanya media pembelajaran yang bersifat nyata untuk memberikan stimulus dan pengalaman belajar pada sisa.

4). Respon siswa

Karakteristik siswa dikelas tersebut sangat beragam, begitu pula respon siswa. Dari hasil wawancara dengan beberapa siswa, mereka mengaku paham dengan materi yang disampaikan. Pengunaan media pembelajaran membuat sswa-siswi tersebut lebih mudah paham dengan materi pelajaran yang disampaikan. Siswa-siswi lebih antusias dan semangat belajar jika menggunakan media pembelajaran. Namun di sisi lain, terdapat siswa yang kurang memperhatikan dalam pelajaran. Ketika guru mengajukan pertanyaan, siswa merasa kurang paham dan tidak bisa menjawab. 


\section{Pembahasan}

Berdasarkan pemaparan hasil penelitian yang telah dijelaskan, maka beberapa masalah yang perlu diselesaikan, sebagai berikut:

a. Aplikasi Media Pembelajaran di Kelas 4 Tema 8 Subtema 3 Bangga Terhadap Daerah Tempat Tinggalku MIN 2 Kebon Agung Imogiri Bantul

Ketika peneliti melaksanakan penelitian, sebelum masuk dikelas dan melihat media yang digunakan peneliti melakukan observasi kepada siswa-siswi di kelas 4. Siswa-siswi tersebut dikategorikan sangat aktif, hal inijuga didukung oleh pernyataan dari wali kelas di kelas 4. Setelah masuk ke ruang kelas untuk meneliti, sejak awal pembelajaran sudah terlihat siswa dikelas tersebut sangat aktif ditambah lagi dengan jumlah siswa yang banyak. Butuh waktu banyak bagi guru untuk menyiapkan media pembelajaran yang digunakan (dalam hal ini proyektor) sebab media tersebut tidak terpasang secara permanen dikelas tersebut. Selain itu, ukuran ruangan kelas yang kecil membuat guru dan siswa tidak leluasa dalam bergerak terlebih dengan jumlah siswa yang banyak.

Permasalah lain yang terjadi adalah media yang digunakan tidak bisa sepenuhnya menjadi alat untuk menyampaikan informasi atau memudahkan dalam memahami materi sebab tidak semua siswa tertarik dan antusias terhadap media tersebut. Terlebih lagi fokus guru selama pembelajaran hanya pada bebepa siswa saja, sementara siswa lainnya tidak terlalu mendapat perhatian. Guru juga terkendala dalam menentukan media yang cocok dengan materi sebab tidak semua materi di buku dapat menggunakan media yang menarik. Untuk materi Bannga Terhadap Daerah Tempat Tinggalku, tidak banyak media yang bisa digunakan sehingga hanya sebatas menggunakan internet dan proyektor.

Selama proses pembelajaran, terlihat guru telah menguasai media yang digunakan sebab sudah pernah digunakan sebelumnya. Guru memulai kelas dengan memberikan stimulus gambar yang berkaitan dengan materi baru setelah itu, memulai pembelajaran. Video di tampilkan selama proses belajar. Video yang ditampilkan berupa 
video tentang berbagai profesi yang mungkin ada disekitar siswa, kemudian bertanya kepada siswa nama dari profesi tersebut.

Selama proses pembelajaran, guru menampilkan lebih dari satu baik gambar maupun video. Namun video yang ditampilkan tidak memiliki suara, sehingga siswa kebingungan dan kesulitan dalam memahami. Dengan media yang digunakan tersebut, terdapat pula beberapa siswa yang tidak memperhatikan pelajaran terutama siswa yang duduk dibelakang. Hal ini karena siswa merasa bosan dan terhalang jika ingin melihat materi yang di berikan lewat media tersebut.

b). Permasalahan yang terjadi dan solusinya

Pelaksanaa pembelajaran yang baik tentu memerlukan persiapan yang baik juga terlebih untuk pembelajaran tematik. Pada kurikulum 2013, telah ditentukan materi yang sesuai dengan tema yang akan diajarkan sehingga guru di tuntut untuk lebih kreatif dan inovatif dalam menyampaikan materi. Tidak hanya itu, guru juga dituntut untuk paham teknologi guna memudahkan guru dalam mengajar sebab banyak hal yang bersinggungan dengan teknologi. Terkait media pembelajaran, banyak jenis media yang bisa digunakan dan sangat beragam tergantung kreatifitas guru. Namun yang menjadi kendala adalah banyak guru yang masih belum menguasai media yang ada. Oleh karena itu, beberapa hal yang dirasa bisa menjadi solusi terkait permasalahan tersebut adalah:

Pertama. Terkait pemilihan dan aplikasi media pembelajaran dikelas, guru perlu menganalisis dan memahami terlebih dahulu materi yang hendak diajarkan. Setelah menganalisis dan memahami materi, guru bisa menentukan media pembelajaran yang akan digunakan. Usahakan media yang digunakan sesuai dengan karakteristik atau jenis materi yang hendak diajarkan sehingga media pembelajaran bisa sesuai dengan materi yang hendak diajarkan.

Kedua. Terkait kesulitan guru mengaplikasikan media pembelajaran dikelas, hal ini menjadi tanggung jawab semua guru membuat pembelajaran dikelas semenarik dan seefektif mungkin. Kesulitan pengaplikasian media dapat teratasi jika guru mampu 
menguasai media yang digunakan. Hal ini penting sebab media menjadi salah satu sarana untuk memudahkan siswa menerima pembelajaran. Seorang guru hendaknya terus belajar dan mengasah kemampuannya. Saat guru memberikan materi tentang profesi disekitar siswa, guru tidak hanya menggunakan media gambar atau video tapi bisa memberikan contoh real seperti diri guru sendiri sebagai seorang guru merupakan salah satu profesi yang ada disekitar siswa.

Ketiga. Terkait fokus peserta didik dikelas. Disini perlu adanya pemikiran yang kreatif dari guru untuk meciptakan suasana belajar yang menyenangkan dan media yang menarik sehingga siswa antusias dalam belajar. Guru juga bisa memberikan stimulus di awal pembelajaran. Stimulus yang digunakan juga harus menarik seperti bernyanyi atau game sederhana yang mengedukasi anak. Ketika anak telah tertarik dengan pembelajaran sejak awal maka ia akan lebih merasa antusias dalam pembelajaran selanjutnya.

Keempat. Terkait kondisi kelas yang sempita dan sarana prasarana yang belum memadai untuk menunjang pembelajaran, ini menjadi tanggung jawab sekolah dalam meningkatkan kualitas sekolah dan fasilitas yang ada agar proses pembelajaran dapat berjalan efisien. Pemenuhan fasilitas tersebut bisa dimulai dari hal-hal kecil terlebih dahulu seperti penataan ruang kelas.

Selama proses pembelajaran berlangsung, diusahakan guru memberikan perhatian kepada peserta didik yang kurang aktif atau tidak memperhatikan pembelajaran karena bisa jadi siswa tersebut belum paham dengan materi yang disampaikan. Siswa tersebut masih mengalami kesulitan meski telah menggunakan media pembeajaran.

Ketercapaian tujuan pembelajaran merupakan salah satu hal penting dalam pendidikan. Oleh karena itu, media merupakan salah satu faktor yang bisa membuat tujuan pembelajaran tersebut dapat tercapai. Pemilihan media yang sesuai, penguasaan media dan aplikasinya dikelas menjadi salah satu kunci pembelajaran dapat tersampaikan dengan baik. 
c). Pengembangan media pembelajaran

Terkait pengembangan media pembelajaran, di MIN 2 Bantul guru belum pernah mencoba mengembangkan media pembelajaran. Hal ini dikarenakan keterbatasan kemampuan guru dalam bidang tersebut fokus guru lebih ke materi pembelajaran. Peneliti belum melakukan pengembangan media di MIN 2 Bantul dikarenakan waktu penelitian yang sering bersamaan dengan waktu ujian dan ulangan semester sehingga tidak banyak waktu yang bisa digunakan untuk pengembangan media. Hal ini menjadi pembelajaran bagi peneliti agar kedepannya pengembangan media pembelajaran dapat dilakukan.

\section{Penutup}

Dari hasil penelitian dan pembahasan diatas, maka kesimpulan dari pembahasan ini sebagai berikut.

Media pembelajaran yang digunakan di kelas 4 pada pembelajaran Tema 8 Subtema 3 Bangga Terhadap Daerah Tempat Tinggal ku di MIN 2 Kebon Agung Imogiri Bantul adalah media internet dan proyektor. Media tersebut digunakan untuk menyampaikan materi tentang berbagai kegiatan produksi dan profesi yang ada disekitar siswa melalui gambar dan video. Yang menjadi kendala pada aplikasi media pembelajaran tersebut adalah guru mengalami kesulitan dalam menentukan media yang digunakan sebab tidak semua materi bisa menggunakan media yang menarik. Hal ini juga dikarekan keterbatasan guru dalam menguasai media pembelajaran.

Dalam proses belajar mengajar, fokus guru tidak diberikan kepada semua siswa sehingga masih terdapat siswa yang kurang memperhatikan dan tidak tertarik dengan media dan materi selama proses pembelajaran. Meskipun begitu banyak juga siswa yang antusias dan paham materi yang diajarkan terlepas dari penggunaan media dikelas. Sehingga kegiatan pembelajaran tersebut dapat dikatakan berjalan cukup baik karena masih terdapat beberapa masalah didalamnya. 


\section{DAFTAR PUSTAKA}

Anitah, Sri. Media Pembelajaran, Surakarta: Yuma Pustaka, 2010.

Arsyad, Azhar. Media Pembelajaran, XVI, Jakarta: RajaGrafindo Persada Pers.

Asnawir dan Usman Basyiruddin. Media Pembelajaran, Jakarta: Ciputat Pers, 2002.

Asyhar, Rayandra. Kreartif Mengembangkan Media Pembelajaran, Jakarta: Gaung Persada Press, 2011.

Djamarah, Syaiful Bahri. Strategi Belajar Mengajar, Jakarta: Cet. 4, Reineka Cipta.

Haling, Abdul. Perencanaan Pembelajaran, Cet-4; Makasar: Badan Penerbit UNM.

Hamdani. Strategi Belajar Mengajar, Bandung: CV Pustaka Setia.

Kustandi, Cecep. Media Pembelajaran, Cet.1, Bogor: Penerbit Ghalia Indonesia, 2013.

Sadiman Arif, S. Media Pendidikan Pengertian, Pengembangan dan Pemanfaatannya, Jakarta: PT RajaGrafindo Persada, 2011.

Sanjaya, Wina. Media Komunikasi Pembelajaran, Jakarta: Kencana Pramedia Group, 2012.

Setyosari, Punaji. Metode Penlitian Pendididkan dan Pengembangan, Jakarta: Prenamedia Group, 2013.

Sukiman, Pengembangan Media Pembelajaran, cet.1, Yogya: Pedagogia, 2012. 
